\title{
Study the effect of adding Cuminum cyminum seeds in the diet on semen characteristics and hormones level in serum of local bucks Sadeq jaafer Zalzala
}

Department of Surgery and Obstetrics,College of Veterinary Medicine, Baghdad University, Iraq. E-mail: $\underline{\text { sadeq.jaffar1@gmail.com }}$

Received: 8/8/2016

Accepted: 28/9/2016

\section{Summary}

This study was conducted on sixteen local Iraqi bucks aged 3 to 4 in College of Veterinary Medicine/ University of Baghdad from January to May, 2016. They were divided randomly into two equal groups; $1^{\text {st }}$ group (G1) was treated by oral administration of $15 \mathrm{gm} /$ daily cumin seeds for 3 weeks, while the $2^{\text {nd }}$ group (G2) represented control group. The $1^{\text {st }}$ group showed a significant $(\mathrm{P} \leq 0.05)$ increase in semen volume $(2.08 \pm 0.36 \mathrm{ml})$; furthermore, the number of sperms increased significantly also according to assessment of semen color (4.23 \pm 0.26$)$. Mass and individual motility showed significant higher level in the $1^{\text {st }}$ group $(86.00 \pm 1.97,87.00 \pm 1.62 \%$, respectively), than in the control group. Significant increase in cortisol and testosterone level was recorded in the $1^{\text {st }}$ group as compared with the $2^{\text {nd }}$ group. In conclusion, cumin seeds enhanced improvement of semen bucks quality.

Keywords: Cuminum cyminum, buck, Semen, Cortisol hormone, Testosterone hormone.

Introduction
Goat, are considered one of small
ruminants whose meat and milk can be used in
human food, few studies made on male goats
as compared with bovine and ovine in Iraq
related with using medical plants for reproduce
improvement ( 1 and 2 ). Herbal medicine is an
important part of modern medicine, it is based
on the use of plants and their extracts,

Cuminum cyminum is an aromatic, astringent herb, it is considered as one of the medical and nutritional sources because of its properties (3). Cuminum cyminum contains various chemical components, the main components are flavonoids by which cumin characterized by the antioxidant activity (4 and 5). Cumin seeds, oil and fruit are all used because of their nutritional value which contains protein, carbohydrate, vitamins and minerals (6 and 7). After puberty there were significant rise in SSH and ICSH level and this controversially before puberty (8). A correlation between testosterone hormone and testes size at puberty age were reported (9). While adding cumin seeds caused an increase in the testosterone level, size and weights of testes, improving in semen quality and sexual behavior (10).

There were link between better nutrition and higher sperm producing parenchyma in the testes of animals (11). The effect of adding parsley seeds and vitamin $E$ on the reproduction trait of Karadi ram lambs, as feed additive caused an enhancement, and shortening the age of puberty (9). Many workers found that adding different medical plants (Zingiber officinale, Eruca sativa and Nigella sativa) enhances the puberty (12 and 13). The aim of this study was to evaluate the effect of using cumin seeds daily feeding of local bucks on semen properties and concentrations of testosterone and cortisol.

\section{Materials and Methods}

This study was conducted on 16 local Iraqi bucks aged between $3-4$ years in the Animal Farm/ College of Veterinary Medicine/ Baghdad University. From January to May 2016 animals were fed on hay, bran and concentrated diet. Animals were divided into two equal groups randomly according to the type of treatment; G1 treated with15gm cumin seeds/ buck orally for 3 weeks daily, the G2 represented control group.

Semen samples were collected by using artificial vagina (A.V.) before and after treatment at intervals 3 weeks, bucks semen quality were examined for physical traits including semen ejaculation volume $(\mathrm{ml}),(14)$, color (15), sperms concentration in addition to individual and mass motility (14). The color of semen was recorded immediately by naked eye and the color was assessed (15), Table (1). 
Table, 1: The color of semen according to Evan and Maxwell (1987).

\begin{tabular}{cccc}
\hline Score & Consistency & \multicolumn{2}{c}{ No. of sperm $\left(10^{9}\right) / \mathrm{ml}$} \\
\cline { 3 - 4 } & & Mean & Range \\
5 & Thick creamy & $\mathbf{5 . 0}$ & $\mathbf{4 . 5}-6.0$ \\
4 & Creamy & $\mathbf{4 . 0}$ & $\mathbf{3 . 5}-4.5$ \\
3 & Thin creamy & $\mathbf{3 . 0}$ & $\mathbf{2 . 5 - 3 . 5}$ \\
2 & Milky & $\mathbf{2 . 0}$ & $\mathbf{1 - 2 . 5}$ \\
1 & Cloudy & $\mathbf{1 . 0}$ & $\mathbf{0 . 3 - 1 . 0}$ \\
0 & Clear watery & Insignificant & Insignificant \\
\hline
\end{tabular}

Serum levels of cortisol and testosterone hormones before and after treatment were examined by using specific kits and gamma counter by Alnadaer Clinical Laboratory in radioimmunoassay (RIA) (16). T. test and F. test were used for Statistical analyses (17).

\section{Results and Discussion}

This was the first trial done on bucks, so there are no available related researches. Results showed a significant $(\mathrm{P} \leq 0.05)$ increase in semen volume $(2.08 \pm 0.36 \mathrm{ml})$; color $(4.23$ \pm 0.26 ) in the treated group (Table, 2). Also in sperm concentration $\left(4.14 \pm 0.12 \times 10^{9} / \mathrm{ml}\right)$ (Table, 3) and mass and individual motility

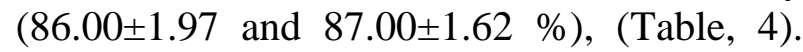
Cumin seeds contain flavonoids which have antioxidant activity that stimulate antioxidant system which have similarity to the chemical structure of sex hormone earned some isoflavonoids androgenic effects in mammals (18). Besides, cumin seeds act as stimulant to the sexual organs and libido in both male and female (19). In addition, cumin seeds are rich in vitamin $\mathrm{E}$ (20), which has a vital effect to stimulate the pituitary gland to produce interstitial cell stimulated hormone (ICSH), then causing an increase in the testosterone production that is in turn affecting the volume and number of spermatozoa. The high individual and mass motilities in G1 might be belonged to the minerals present in Cuminum cyminum as iron, calcium and phosphorus as well as its content of vitamins such as thiamin, riboflavin and niacin (20). Calcium plays an important role in inhibition of phosphordie strase enzyme, which lessens the concentration of cAMP responsible for activation of sperm motility (21). The same results were observed by using Zingiber officinale (22) and using Eruca sativa (23). The decrease in the percentages of dead sperms in the treated group might be due to its content of flavonoids and vitamin E. (24) howed similar trend using Zingiber officinale.

Table, 2: Effect of cumin seeds on volume $(\mathrm{ml})$ and color of semen for local Iraqi bucks $(\mathrm{M} \pm \mathrm{SE})$.

\begin{tabular}{|c|c|c|c|c|c|}
\hline \multirow[b]{2}{*}{ Groups } & \multirow[b]{2}{*}{$\begin{array}{l}\text { No. of } \\
\text { Animals }\end{array}$} & \multicolumn{2}{|c|}{ Volume } & \multicolumn{2}{|c|}{ Color } \\
\hline & & $\begin{array}{c}\text { Pre } \\
\text { Treat. }(\mathrm{ml})\end{array}$ & $\begin{array}{c}\text { Post } \\
\text { Treat. }(\mathrm{ml})\end{array}$ & $\begin{array}{c}\text { Pre } \\
\text { Treat. }\end{array}$ & $\begin{array}{c}\text { Post } \\
\text { Treat. }\end{array}$ \\
\hline G1 & 8 & $\begin{array}{c}1.62 \\
\pm 0.45 \\
\text { a }\end{array}$ & $\begin{array}{c}2.08 \\
\pm 0.36 \\
\text { b }\end{array}$ & $\begin{array}{c}2.98 \\
\pm 0.58 \\
\text { A }\end{array}$ & $\begin{array}{c}4.23 \\
\pm 0.26 \\
\text { B }\end{array}$ \\
\hline G2 & 8 & $\begin{array}{c}1.58 \\
\pm 0.57 \\
\text { a }\end{array}$ & $\begin{array}{c}1.45 \\
\pm 0.76 \\
\text { a }\end{array}$ & $\begin{array}{c}3.07 \\
\mathbf{\pm 0 . 2 7} \\
\text { A }\end{array}$ & $\begin{array}{c}3.15 \\
\pm 0.34 \\
\text { A }\end{array}$ \\
\hline
\end{tabular}

*Different small letters mean sig. difference $\mathbf{P}<\mathbf{0 . 0 5}$

*Different capital letters mean sig. difference $\mathbf{P}<0.05$

Table, 3: Effect of cumin seeds on sperm concentration. $(\mathrm{M} \pm \mathrm{SE})$.

\begin{tabular}{cccc}
\hline Groups & $\begin{array}{l}\text { No. of } \\
\text { Animals }\end{array}$ & $\begin{array}{c}\text { pre treatment } \\
\left(\times 10^{9} / \mathrm{ml}\right)\end{array}$ & $\begin{array}{c}\text { Post treatment } \\
\left(\times 10^{9} / \mathrm{ml}\right)\end{array}$ \\
\hline G1 & $\mathbf{8}$ & $\mathbf{3 . 2 4} \pm \mathbf{0 . 2 6}$ & $\mathbf{4 . 1 4} \pm \mathbf{0 . 1 2}$ \\
& & $\begin{array}{c}\mathbf{a} \\
\mathbf{b}\end{array}$ & $\begin{array}{c}\mathbf{3} \\
\mathrm{G} 2\end{array}$ \\
& $\mathbf{8}$ & $\begin{array}{c}\mathbf{3 . 1 5} \pm \mathbf{0 . 2 2} \\
\mathbf{a}\end{array}$ & $\begin{array}{c}\mathbf{3 . 1 7} \pm \mathbf{0 . 3 4} \\
\mathbf{a}\end{array}$ \\
\hline
\end{tabular}

*Different letters mean sig. difference at $\mathbf{P}<0.05$.

Results showed a significant $(\mathrm{P} \leq 0.05)$ elevation in cortisol level in G1 (13.22 \pm 1.82 $\mathrm{nmol} / \mathrm{ml})$, and in testosterone level $(4.72 \pm 0.42$ $\mathrm{nmol} / \mathrm{ml}$ ) in comparison with G2 Post treatment (Table, 5). Cortisol is synthesized in the adrenal cortex, and its production is stimulated by physical stress, emotional and psychological (25). The increase in cortisol level in G1 might be owing to cumin seeds as it stimulates the hypothalamus pituitary adrenal system resulting in adrenocorticotropic hormone secretion (ACTH) that stimulates adrenal gland to secrete glucocorticoid from the adrenal cortex. The high level of testosterone in G1 might be due to that cumin acts as a stimulant to the sexual organs and libido in both male and female due to its containing vitamin E (19 and 26) beside to its antioxidant activity that increase levels of tRNA and mRNA for synthesis of leydig cells for the hormone (27) also the flavonoids affect leydig cell to produce testosterone hormone (20 and 28). In conclusion, cumin seeds in diet of Iraqi bucks improve the semen characteristics (volume, color, concentration and motility) as well as elevates testosterone and cortisol values. 


\begin{tabular}{|c|c|c|c|c|c|c|c|}
\hline \multirow{2}{*}{ Groups } & \multirow{2}{*}{$\begin{array}{c}\text { No. of } \\
\text { Animals }\end{array}$} & \multicolumn{2}{|c|}{ Mass motility } & \multirow{2}{*}{ I } & \multicolumn{2}{|c|}{ Individual motility } & \multirow{2}{*}{ I } \\
\hline & & Pre treatment \% & Post treatment \% & & Pre treatment \% & Post treatment \% & \\
\hline G1 & 8 & $\begin{array}{c}77.00 \pm 1.76 \\
\mathrm{a}\end{array}$ & $\begin{array}{c}86.00 \pm 1.97 \\
\text { b }\end{array}$ & 0.57 & $\begin{array}{c}80.00 \pm 1.54 \\
\text { a }\end{array}$ & $\begin{array}{c}87.00 \pm 1.62 \\
\text { b }\end{array}$ & 0.48 \\
\hline G2 & 8 & $\begin{array}{c}76.00 \pm 1.65 \\
a\end{array}$ & $\begin{array}{c}78.00 \pm 1.53 \\
\mathrm{a}\end{array}$ & 0.42 & $\begin{array}{c}79.00 \pm 1.63 \\
\mathrm{a}\end{array}$ & $\begin{array}{c}81.00 \pm 1.35 \\
\mathrm{a}\end{array}$ & 0.58 \\
\hline
\end{tabular}

*Different small letters mean sig. difference at $\mathbf{P}<\mathbf{0 . 0 5}$.

Table , 5: Effect of cumin seeds on serum cortisol and testosterone hormones level. $(\mathrm{M} \pm \mathrm{SE})$.

\begin{tabular}{|c|c|c|c|c|c|c|c|}
\hline \multirow{2}{*}{ Groups } & \multirow{2}{*}{$\begin{array}{c}\text { No. of } \\
\text { Animals }\end{array}$} & \multicolumn{2}{|c|}{ Cortisol } & \multicolumn{4}{|c|}{ Testosterone } \\
\hline & & $\begin{array}{c}\text { Pre treatment } \\
\mathrm{nmol} / \mathrm{ml}\end{array}$ & $\begin{array}{c}\text { Post treatment } \\
\mathrm{nmol} / \mathrm{ml}\end{array}$ & & $\begin{array}{c}\text { Pre treatment } \\
\mathrm{nmol} / \mathrm{ml}\end{array}$ & $\begin{array}{c}\text { Post treatment } \\
\mathrm{nmol} / \mathrm{ml}\end{array}$ & \\
\hline G1 & 8 & $\begin{array}{c}7.46 \pm 0.19 \\
\mathrm{a}\end{array}$ & $\begin{array}{c}13.22 \pm 1.82 \\
\text { b }\end{array}$ & 1.02 & $\begin{array}{c}3.47 \pm 0.16 \\
\mathrm{a}\end{array}$ & $\begin{array}{c}4.72 \pm 0.42 \\
b\end{array}$ & 0.13 \\
\hline G2 & 8 & $\begin{array}{c}8.23 \pm 0.26 \\
\mathrm{a}\end{array}$ & $\begin{array}{c}8.79 \pm 0.38 \\
a\end{array}$ & 0.40 & $\begin{array}{c}3.25 \pm 0.27 \\
\mathrm{a}\end{array}$ & $\begin{array}{c}3.56 \pm 0.13 \\
a\end{array}$ & 0.36 \\
\hline
\end{tabular}

*Different small letters mean sig. difference $\mathbf{P}<\mathbf{0 . 0 5}$

\section{References}

1. Jainudeen, M. R. and Hafez, E. S. E. (1987). Reproduction in farm animals. E. S. E. Hafez, ed. Lea and Febiger, Philadelphia.

2. AL-Kindi, A.; Kadim, I.T.; Mahmoud, I.Y.; Mahgoub, O.; Plude, J.; AL-Maani, M. and Bakheit, C.S. (2005). Physiological response of two age groups of Omani male goat to short road transportation in relation to circulating levels of sex steroids and plasma chemistry. J. Anim. Vet. Advan., 4(8):742746.

3. Zaman, U. and Abbasi, A. (2009). Isolation, purification and characterization of a nonspecific lipid transferprotien from Cuminum cyminum. Inter. Chem. Biol. Sci. Res. Pakistan. 3:24-29.

4. Thippeswamy, N.B. and Nadiu, K.A. (2005). Anti oxidant potency of cumin varieties cumin black cumin and bitter cumin on oxidant systems. Eur. Food Res. Technol., 220:472-476.

5. Tapsell, L.C. (2006). Health benefits of herbs and spices: the past, the present and the future. Med. J. Aust., 38:170-224.

6. Sayyah, M.; Peirovi, A. and Kamalinejed, M. (2003). Anti-nociceptive effect of the fruit essential oil of Cuminum cyminum L. in rat. Iran, J. Biomed., 6(4):141-145.

7. Agarwal, W.; Gupta, V.; Nepali, K.; Suri, O. and Dhar, K. (2010). Chemical and biological characterstics of Cuminum cyminum. J. Nutr., 1(1):148-156.

8. Al-Zwein, D. H. (2008). Effect of parsley petroselinum sativum on some physiological (hematological and reproductive) and productive traits of Awassi male sheep. Ph.D. Thesis, College of Veterinary Medicine, Baghdad University.

9. Ramzi, D.O. (2010). A study on the effect of vitamin E and Parsley seeds administration at different ratios of concentrate diet on productivity,physiological and reproductively traits of male Karadi lambs, Ph.D. Thesis, College of Veterinary Medicine, Baghdad University.

10. Tamara N. and Mudhaffar AL-Saigh N.R. (2014). Effect of vasectomy and / or adding Cuminum cyminum seeds in the diet of Awassi ram lambs on their carcasses traits Iraqi J. Vet. Med., 38(2):79-86.

11. Bielli, A.; Gasteli, T.; Perez, R.; lopez, A.; Castrilleo, M.; Forsberg, M. and Rodrigue, M. (1997). Influence of nutrition on seasonal variation in testicular morphology in corriedale rams. J. Reprod., 43:171-180.

12. Al-Musawey, J.E. (2009). A study on the effect of using Zingiber officinale and Eruca sativa in some productivity, physiological traits and reproductive characteristics of male Awassi lambs. M.Sc. Thesis, College of Veterinary Medicine, Baghdad University.

13. Al-Saady, M.J.L. (2010). Effect of Nigella sativa and/or Trigonella foenum graecum seeds on some productive and physiological traits of Awassi ram lambs. Ph.D. Thesis, College of Veterinary Medicine, Baghdad University.

14. Chemineau, P.; Cagnie, Y.; Guerin, Y.; Orgeur, P. and Vallet, J. C. (1991). Training 
manual on artificial insemination in sheep and goats. FAO, Animal Production and Health, 83:1.

15. Evans, G. and Maxwell, W.M.C. (1987). Salamons Artificial Insemination of Sheep and Goats. Butter Worths, Sydney, Australia, Pp:123-194.

16. Berga, S. and Dainiels, T. (1991). Use of the laboratory in disorder of reproductive neuro endocrinology. J. Clin. Immunoassay. 14:2338.

17. Steel, R.G.D. and Torri, H.J. (1986). Principles and procedures of statistics. $2^{\text {nd }}$ Edition, McGraw Hill., London.

18. Hertog, M.G.L.; Feskens, E.J.M.; Hollman, P.C.H.; Katan, M.B. and Kromhout, D. (1993). Daitary antioxidant flavonoids and risk of coronary heart disease. The Zupthen Elderly study. Lancet; 342:1007-1011.

19. Geo, T.; Grossberg, M. D. and Barry, F. (2007). The Essential Herb-drug Vitamin Interaction Guide, Pp:176-177.

20. Gachkar, L.; Yadegeri, D.; Rezaei, M. B.; Taghizadeh, M.; Astaneh, A. S. and Rasoli, I. (2006). Chemical and biological characteristics of Cuminum cyminum and Rosmarinus officinalis essential oils. Iran. J. Biol., 18(3):101-102.

21. Nassar, A.; Mahony, M.; Blackmore, P.; Morshadi, M.; Ozgur, K. and Ochninger, R. (1998). Increase of intercellular calcium is not cause of peroxifyline induced hyperactivation or acrosome reaction in human sperm. Fertil. Steril., 69:745-749.

22. Al-Rawi, S. T. (2008). Effect of using
Zingiber officinale and vitamin $\mathrm{E}$ on productivity, physiological and reproductivity traits of Awassi male lambs. M.Sc. Thesis. College of Veterinary Medicine, Baghdad University.

23. Al-Fityin, M. H. (2008). Effect of adding Eruca sativa and vitamin $\mathrm{E}$ in the diet on some productivity, reproductivity and haematological traits of Awassi ram lambs. M.Sc. Thesis, College of Veterinary Medicine, Baghdad University.

24. Kamtchouing, P.; Mbongue, F.; Dimo, T. and Jasta, H. B. (2002). Evaluation androgenic activity of Zingiber officinale in male rats. Asian J. Androl.; 4(4):200-201.

25. Emslie-Smith, D.C.; Paterson, C.; Scratcherd, T. and Read, N. (1988). Textbook of Physiology. Churchill Living Stone, Edinburgh. Pp:497-509.

26. Mokhtari, M. and Shahid, S.(2005). The effect of Cuminum cyminum alcoholic extraction on serum testosterone level and its contraceptive effect on adult male rats. J. Med. Sci. Health, 13(50):8-13.

27. Satyanarayana, S.; Sushruta, K.; Sarma, G.; Srinivas, N. and Subba, G. (2004). Antioxident activity of the aqueous extracts of spicy food additives. J. Herbal Pharmacol, $4(2): 1-10$.

28. Gagandeep, M.; Dhanalakshmi, S.; Mendiz, E.; Rao, A. and Kale, R. (2003). Chemo preventive effects of Cuminum cyminum in chemically induced for stomach and uterine cervix tumors in murine model systems. Nutr. Canc., 47:171-180.

$$
\begin{aligned}
& \text { دراسة تأثير إضافة بذور الكمون إلى عليقة ذكور المعز المحلي في صفات السائل المنوي ومستوى هورموني }
\end{aligned}
$$

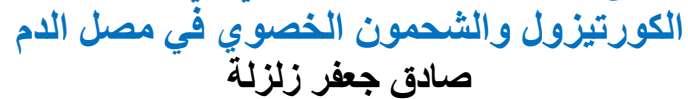

$$
\begin{aligned}
& \text { فرع الجر احة و التوليد، كلية الطب البيطري، جامعة بغداد، العراق. } \\
& \text { E-mail: sadeq.jaffar1@gmail.com } \\
& \text { الخلاصة }
\end{aligned}
$$

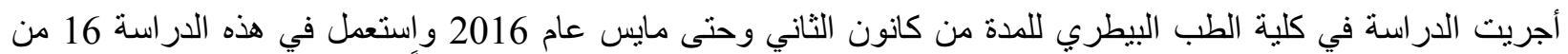

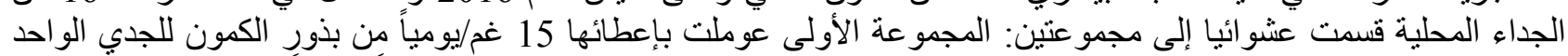

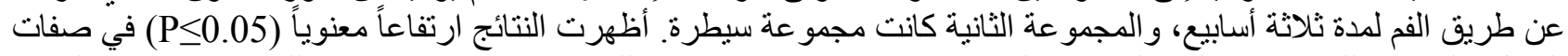

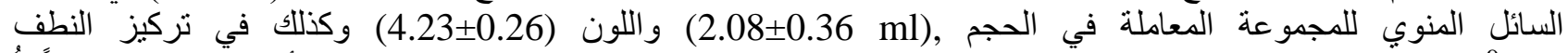

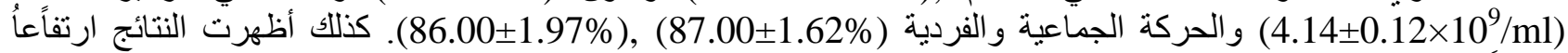

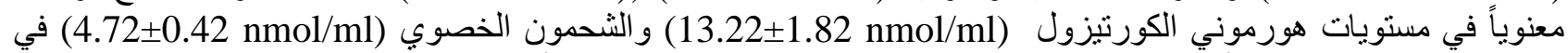

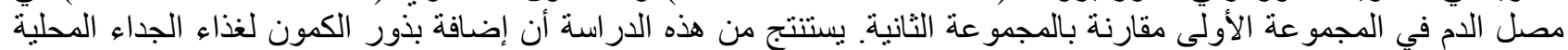

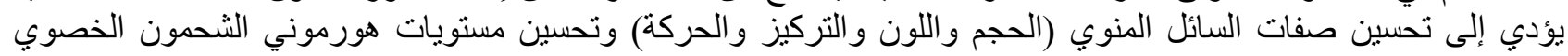

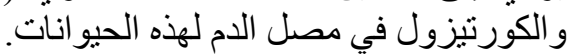
الكلمات المفتاحية: بذور الكمون، الجدي، السائل المنوي، هورمون الكورنيزول، الشحمون الخصوي. 